Keynote Address - Clinic, the University and Society

\title{
CLINICAL LEGAL EDUCATION IN A DANGEROUS TIME
}

Sarah Buhler, University of Saskatchewan, Canada*

\section{Introduction}

I am honoured to have the opportunity to speak this afternoon. I would like to begin by acknowledging that this city, Toronto, is located on the traditional Indigenous territory of the Haudenosaunee people and more recently the Mississaugas of the New Credit. This land where we are holding this conference was also the subject of the Dish With One Spoon Wampum Belt Covenant, which was an agreement between the Iroquois Confederacy and the Ojibwe and allied nations to share and care for the resources around the Great Lakes. This territory is also covered by the Upper Canada Treaties. ${ }^{1}$ This is powerful territory that has always been a meeting place for Indigenous nations and it is a very good place for us to gather to learn together about the risks and rewards of clinical legal education.

I come to you from $2800 \mathrm{~km}$ away - from the City of Saskatoon, in the Province of Saskatchewan - half way across this country. My city is located on Treaty 6 Territory, which is also the homeland of the Metis Nation. I am the great

\footnotetext{
*Sarah Buhler is an Associate Professor in the College of Law at the University of Saskatchewan. ${ }^{1}$ See First Story Toronto, "First Story Toronto: Exploring the Aboriginal History of Toronto!" online at https://firststoryblog.wordpress.com/aboutfirststory/ (accessed November 18, 2016) and Sara McDowell, "The Indigenous History of Toronto" (University of Toronto Libraries) online at http://guides.library.utoronto.ca/Toronto (accessed November 18, 2016).
} 
Keynote Address - Clinic, the University and Society

granddaughter and granddaughter of Russian Mennonite farmers who came to settle just north of Saskatoon in the late 1800s and early 1900s. My grandparents came to Canada as refugees fleeing civil war, displacement and the loss of their way of life. ${ }^{2}$ The Canadian government promised my people land and religious freedom and my people prospered. ${ }^{3}$ Around the same time, Canadian government policies were leading to starvation, illness and poverty in Indigenous communities. Indigenous people were being moved to reserves; their children were being forced to go to residential schools where many were horribly abused and many died; Indigenous spiritual practices were outlawed. ${ }^{4}$ Today, in Saskatchewan, where I live, settler colonialism and racism are still alive and well. ${ }^{5}$ To give just one example- while Indigenous people make up $15 \%$ of the province's population, close to $80 \%$ of people in Saskatchewan prisons are Indigenous. ${ }^{6}$ The

\footnotetext{
2 See Mennonite Historical Society of Canada, "Coming to Canada" online at http://www.mhsc.ca/index.php?content=http://www.mhsc.ca/mennos/hcanada.html (accessed November 18, 2016).

${ }^{3}$ Indeed, the settlement of Mennonite farmers in western Canada was directly connected to the national colonial project. See Leo Driedger, "Native Rebellion and Mennonite Invasion: An Examination of Two Canadian River Valleys" (1972) The Mennonite Quarterly Review 298. Driedger writes (at p. 300) that "early Mennonite settlers in Manitoba and Saskatchewan benefitted greatly from Canadian government conquest and control of Metis and Indians in the West."

${ }^{4}$ See generally, James Daschuk, Clearing the Plains: Disease, Politics of Starvation, and the Loss of Aboriginal Life (Regina: University of Regina Press, 2013).

${ }^{5}$ As Patrick Wolfe has shown, settler colonialism is not a past event, but is rather an ongoing structure that is ongoing in the present moment. See Patrick Wolfe, "Settler Colonialism and the Elimination of the Native" (2006) J of Genocide Research 387 at 388.

"Statistics Canada, "Adult Correctional Statistics in Canada 2014/2015", online at http://www.statcan.gc.ca/pub/85-002-x/2016001/article/14318/tbl/tbl05-eng.htm (accessed November 19, 2016); and Government of Saskatchewan, "Saskatchewan Aboriginal Peoples: 2011 National Household Survey",
} 
Keynote Address - Clinic, the University and Society

legal clinic that I am involved with - Community Legal Assistance Services for Saskatoon Inner City (CLASSIC) assists clients with prison discipline hearings, criminal charges, complaints against police, evictions and housing issues, income assistance, employment law, human rights and more. ${ }^{7}$ Many of our clients find themselves at the clinic because of the ongoing traumatic impacts of colonialism. ${ }^{8}$ Meanwhile, the opportunities I have had in my life for education, security, and stability flow in many ways directly and indirectly from the land that was granted to my forebears. ${ }^{9}$

I share a little bit about where I come from and where I am located and a little bit about the dynamics in my home community because I have learned that it is important for us to always situate ourselves so that it might become clear that we are all coming from different places, and to underscore the fact that our knowledge and ideas are contingent and rooted in particular places and histories. ${ }^{10}$

http://www.stats.gov.sk.ca/stats/pop/2011Aboriginal\%20People.pdf (accessed November 19, 2016).

${ }^{7}$ See www.classiclaw.ca

8 For one study showing the ways that colonialism produces "trauma trails" in the present day lives of people, see Judy Atkinson, Trauma Trails, Recreating Song Lines: the Transgenerational Effects of Trauma in Indigenous Australia (Sydney: Spinifex, 2002).

${ }^{9}$ Esther Epp-Thiessen, "Mennonites Colonizing Canada and the US" (2014) 2 Intersections: MCC theory and Practice Quarterly p13, online at :

http://mcccanada.ca/sites/mcccanada.ca/files/media/common/documents/intersectionswinter2014 web.pdf and see Driedger, supra note 3.

${ }^{10}$ See Lisa Monchalin, who writes that "This presentation of the instructor [or researcher] as a subjective self is important and must not be glossed over given the colonial past and present" and "We must acknowledge that where one stands in the world affects one's view". Lisa Monchalin, The Colonial Problem: An Indigenous Perspective on Crime and Injustice in Canada (Toronto: University of Toronto Press, 2016) at xvii and xix. 
Keynote Address - Clinic, the University and Society

This situating of ourselves is particularly important when we consider our roles and relationships in clinical legal education. None of us are positioned neutrally in relation to the world or to our work in clinics. When I look around this room, I see people from around this country and from around the world. Each of you has your own personal story and history, and each are engaged in the long struggle for justice as it unfolds in the particular places where you work. But, because of the complicated global forces that operate in our world, we are also connected together and entangled together in some really important ways, facing versions of the same risks in our own local contexts. And this is why it makes so much sense to come together from around the world to share our experiences and learn together.

\section{A world in crisis}

The theme of this conference is the "risks and rewards of clinical legal education". When I first heard about this theme, I was particularly struck by the word "risk". Risk is a word that feels so reflective of our world right now, and I thought I would try to think about where clinical legal education is situated in the larger world of risk and crisis that we inhabit today - what our role is in relation to this world and what the rewards of clinical legal education in our world of risk and endless crisis might be. 
Keynote Address - Clinic, the University and Society

So let us take a moment to consider the state of the world in which we find ourselves today, July tenth 2016 - my son Ben's $8^{\text {th }}$ birthday. I don't think that anyone can dispute that we live in a world in crisis, a world that is characterized by harrowing injustice, with a growing sense of fear and unease permeating. Every parent I know holds a sense of worry for the future that his or her children will inherit. I know I wonder and I worry about my Benjamin (and my other 2 children) and how the world will be for them.

We are currently seeing the rise of far right nationalism in Europe and elsewhere. We are seeing the rise of Donald Trump and white supremacism in the United States and an unleashing of an overt racism and xenophobia in many countries. Meanwhile, there are more people displaced today than in any other time in history: one in every 113 people in the world is a refugee, internally displaced or seeking asylum. ${ }^{11}$ Some commentators are noting that what we are living through is the beginning of the ugly end stages of western imperialism and the capitalist world order - a headline in the Guardian a couple of weeks ago referenced a "dying world order". ${ }^{12}$ A June 2016 Globe and Mail article referenced

\footnotetext{
${ }^{11}$ Adrian Edwards, UNHCR, “Global Forced Displacement Hits Record High" (20 June, 2016) online at: http://www.unhcr.org/news/latest/2016/6/5763b65a4/global-forced-displacement-hitsrecord-high.html (access November 22, 2016).

${ }^{12}$ Paul Mason, “The Global Order is Dying. But it's an Illusion to think Britain can Survive without the EU", The Guardian (June 27, 2016) online at: https://www.theguardian.com/commentisfree/2016/jun/27/global-order-britain-survive-eualternative-economic-model (accessed November 22, 2016).
} 
Keynote Address - Clinic, the University and Society

a "gathering storm" on the world stage, noting that "The rise of Mr. Trump, the wars and refugee crises of the Middle East, and the West's sanctions war with Russia have all fed a sense of dangerous instability on the international stage". ${ }^{13}$ Many commentators have noted that a sense of anxiety permeates western culture. $^{14}$ If you want an example, just look at the latest blockbuster films - so many of which are dedicated to helping audiences visualize the spectacular destruction of institutions. Indeed Joseph Masco wrote that American society is imaginatively rehearsing for destruction through its cinema. ${ }^{15}$ Lesley Head, who has written a heart-wrenching book about hope and grief in the face of climate change, has written, "[w]e in the affluent West are grieving for the loss of the modern self and its dependence on a future characterized by hope."16 She notes that there is a sense of "lurking anxiety and looming crisis all around."17

Of course, life for so many on the margins has already, for a very long time, been characterized by violence and loss and risk. Lesley Head writes that the

\footnotetext{
${ }^{13}$ Mark MacKinnon, "Aftershock", Globe and Mail, Saturday June 25, 2016 A8 at A8.

${ }^{14}$ See for example, David Nielson, "Class, Precarity, and Anxiety under Neoliberal Global Capitalism: from Denial to Resistance" (2015) Theory \& Psychology 1.

15Joseph Masco, "Engineering the Future as Nuclear Ruin," in Ann Laura Stoler, ed., Imperial Debris: On Ruins and Ruination (Durham: Duke University Press, 2013) 252 at 279. Masco argues that American nation building is built "not on the protection and improvement of everyday life, but rather on the national contemplation of ruins" (at 252).

${ }^{16}$ Lesley Head, Hope and Grief in the Anthropocene: Re-conceptualizing Human-Nature Relations (New York: Routledge, 2016) at 21.

17 Ibid. See also: Ulrich Beck, Twenty Observations on a World in Turmoil (Cambridge: Polity Press, 2012). Beck writes at 14: "Even in the global economic crisis the wealthy pay at worst in the value of their stocks, whereas the most vulnerable social groups, who have nothing to do with the crisis, are 'paying' for it in the hard currency of their...existence."
} 
Keynote Address - Clinic, the University and Society

"histories of capitalism and colonialism have shown us" that "the hopes of many have been built on other people's suffering." ${ }^{18}$ Critical Indigenous writers and artists have been pointing out for a long time that for Indigenous people, the apocalypse started with the arrival of settler colonialism and continues apace to this day. Indigenous artist Lindsey Nixon writes that we are currently living in an "Indigenous dystopia." ${ }^{19}$ And Anishinaabe scholar Lawrence Gross writes about what he calls "Post Apocalypse Stress Syndrome," noting that the Anishinaabe people are what he calls "postapocalypse people, having seen the end of their respective worlds within historical memory" ${ }^{20}$

In other words, while a growing number of people feel a rising sense of risk, we already live in a world where violence and loss are tearing apart the fabric of communities, where some communities have already experienced forms of apocalypse. There is overt, shocking violence occurring in too many places on our planet. I am thinking today about the destruction of Aleppo. Closer to home I am thinking today of police violence towards Black men and women in Baltimore,

\footnotetext{
${ }^{18} \mathrm{Ibid}$ at 8 .

${ }^{19}$ Lindsay Nixon, "Visual Cultures of Indigenous Futurisms" GUTS Magazine (May 20, 2016) online at http://gutsmagazine.ca/visual-cultures/ (accessed November 22, 2016). See also Karl Hardy, who writes that western utopias have been Indigenous dystopias: Karl Hardy, "Unsettling Hope: Contemporary Indigenous Politics, Settler-colonialism, and Utopianism (2012) 2 Spaces of Utopia: an Electronic Journal 123 at 126. Online at http://ler.letras.up.pt/uploads/ficheiros/10640.\%20Hardy spaces.pdf (accessed November 22, 2016).

${ }^{20}$ Lawrence W. Gross, Anishinaabe Ways of Knowing and Being (Surrey: Ashgate, 2014) at 33.
} 
Ferguson, this week in Baton Rouge, St. Paul, Minnesota, and in this city, Toronto, and in my home community of Saskatoon. But there is also what Rob Nixon has called "slow violence"21, what Paul Farmer calls "structural violence" 22, and what Chris Cuneen calls "the violence of neglect" 23 - in other words the violence of poverty, hunger, loss, and dispossession that affects so many in our communities. It is hard to deny that our economic systems, political structures and legal structures continue to value some lives over others, that they tolerate completely the suffering of some people due to poverty, ill health, unsafe work, unsafe housing, and daily harmful interactions with people wielding official power. ${ }^{24}$ I am thinking of a friend, a young Indigenous man who told me recently of his humiliating encounter with police who stopped him as he was walking home from work one evening. I am thinking of another friend, who grew up trying to protect and watch out for his sisters, young Indigenous girls, as they sold their bodies on the streets of Saskatoon.

But of course, this story of risk, crisis and violence is not the whole story. For every act of violence and destruction, there are many who work to build and

\footnotetext{
${ }^{21}$ Rob Nixon, Slow Violence and the Environmentalism of the Poor (Boston: Harvard University Press, 2013).

${ }^{22}$ See Paul Farmer, Pathologies of Power: Health, Human Rights, and the New War on the Poor (Berkeley: University of California Press, 2005) at 50.

${ }^{23}$ Chris Cuneen, "Indigenous Incarceration: the Violence of Colonial Law and Justice," in Phil Scraton and Jude McCulloch, eds., The Violence of Incarceration (New York: Routledge, 2009) 1. ${ }^{24}$ See generally, James A. Tyner, Violence in Capitalism: Devaluing Life in an Age of Responsibility (Lincoln: Nebraska University Press, 2016).
} 
Keynote Address - Clinic, the University and Society

mend and knit together community. In the wake of slow violence, communities come together to heal, build, and create hope. In every act of dehumanization there are those who deeply honour the dignity of people. In the face of every dystopian imaginary are dreams and visions of a better world. The most powerful movements in this regard have arisen from the communities most deeply affected by injustice - the Blacklives matter that has arisen in the wake of police violence towards black men and women in American cities, ${ }^{25}$ and, closer to home for me, Idle No More, a global movement for justice for Indigenous people that was started by four women in my home city of Saskatoon. ${ }^{26}$ You may think of and name movements for justice and groups working for justice that have arisen in your home communities also. These movements arise from the knowledge and experiences of people who have faced crises and devastating injustice. They do not accept that the world can remain as it is and are moving forward to build a better world.

\section{Where are law schools in this world of risk?}

Where are law schools situated in this world of risk and crisis? Do we accept the world as it is, as if the current situation is natural and inevitable? Do we

\footnotetext{
${ }^{25}$ See: http://blacklivesmatter.com/about/ and

${ }^{26}$ See: http://www.idlenomore.ca/ and see The Kino-nda-niimi Collective, The Winter We Danced: Voices from the Past, the Future, and the Idle No More Movement (Winnipeg: ARP Books, 2014).
} 
Keynote Address - Clinic, the University and Society

navigate the status quo? Or do we stand with those who dream of and work towards a better world? In my experience and understanding, law schools as a rule do not devote a massive amount of attention or time to the consideration of the complex problems that shake our world and to thinking about how law and the legal profession might respond. Indeed, to the contrary, it seems to be the case that at least in Canada, most first year law students spend more time thinking about arcane features of nineteenth century England from which so many of the cases arise than they do seriously contemplating the deep and growing problems of our world at this moment. Of course - that is the legal method - looking backwards for precedent and solutions, while continuously claiming neutrality, placelessness, and what Elizabeth McDowell calls "“"point-of-viewlessness". ${ }^{27}$

In fact, as critical observers have noted, legal education tends to obsessively focus students' attention away from the social, economic and political contexts within which legal problems are created and that, far from promoting neutrality, this approach tends to promote conservative ideological orientations in law students and a desire to maintain the status quo. ${ }^{28}$ In a fascinating study of the discourse practices of first year law school classrooms in the United States,

\footnotetext{
${ }^{27}$ Elizabeth L. MacDowell, "Law on the Street: Legal Narrative and the Street Law Classroom" (2007) 9 Rutgers Race and L. Rev. 285 at 317. See also the discussion in Deborah L. Rhode, The Trouble with Lawyers (Oxford: Oxford University Press, 2015) at 129.

${ }^{28}$ See, for example, Janet Moser, “Legal Education: Nemesis or Ally of Social Movements?" (1997) 35 Osgoode Hall LJ 613;
} 
Keynote Address - Clinic, the University and Society

Elizabeth Mertz observed that law professors routinely stop students from engaging in discussions about morality, justice and political contexts, admonishing them that such discussion is irrelevant to the legal method. ${ }^{29}$ Another powerful critique comes from Robin West, who has recently written about law schools' avoidance of serious discussion about justice and what justice might demand of law and lawyers. West writes: "inside the law schools, inside the classroom...one gleans no indication whatsoever that justice and what it might require are even marginally relevant to the study of law, much less central to it." 30 She goes on: "The near-universal and indeed near-militant avoidance of the concept of justice in the very educational institutions that should centralize its study...is so indefensible (and so rarely defended) as to be fairly labeled pathological." ${ }^{31}$ According to West, by failing to engage with questions of justice, it is as though, "to take a rough analogy, medical schools gave no shrift whatsoever to a study of what it is that makes for a healthy human." 32

The result is that legal education tends to promote what Janet Mosher has called an "anti-critical approach" to lawyering - emphasizing a model where lawyers represent individual clients, and client troubles are understood as

\footnotetext{
${ }^{29}$ Elizabeth Mertz, The Language of Law School: Learning to "Think Like a Lawyer" (New York: Oxford University Press, 2007).

${ }^{30}$ Robin L. West, Teaching Law: Justice, Politics, and the Demands of Professionalism (Cambridge: Cambridge University Press, 2014) at 26.

${ }^{31} \mathrm{Ibid}$ at 27.

${ }^{32}$ Ibid at 26.
} 
Keynote Address - Clinic, the University and Society

individual and private - disconnected from larger forces such as colonialism, racism and economic structures. ${ }^{33}$ Mosher writes that legal education "prepares students to work within the existing order, marginally, incrementally modifying it through ligation," ${ }^{34}$ and goes on to note that "a reasonable deduction which follows is that lawyers trained in this anti-critical educational environment are unlikely to see client problems as anything other than individual problems, are unlikely to search for systemic patterns of oppression, are unlikely to attempt to understand the structural roots of client problems, are even less likely to challenge those structures." ${ }^{35}$ In other words, legal education tends to produce lawyers who see themselves as technocratic solvers of individualized problems, maintainers of the existing order, and ill-prepared to engage with the large, systemic problems that haunt our world.

There are costs to these tendencies in legal education to eschew discussions about justice and to turn away from a moral engagement with the complex problems of the world: some researchers have connected these tendencies at least in part to the widely observed phenomenon of law students becoming dispirited, unhappy and deeply cynical about the possibility of the world becoming better. ${ }^{36}$

\footnotetext{
${ }^{33}$ Supra note 28 at 626.

${ }^{34} \mathrm{Ibid}$.

${ }^{35}$ Ibid.

${ }^{36}$ See Robert Granfield, Making Elite Lawyers: Visions of Law at Harvard and Beyond (New York: Routledge, 1992). On lawyer and law student unhappiness and cynicism more generally, see
} 
Keynote Address - Clinic, the University and Society

And the legal profession as a whole is undermined when we fail to centralize the advancement of justice in our law schools: as Sameer Ashar has argued, the legal profession's social power depends at least in part on a public conception that it has an interest in a wider public good and this power is eroded when we fail to take this focus on the wider public good seriously. ${ }^{37}$

Of course, I know it is more complicated than I have described - and there are strong countercurrents within legal education (beyond clinics) that seek to deal with questions of justice and the role of the legal profession in advancing justice in our world. Law students themselves have incredible agency to resist the dominant messages that they receive and work towards justice. But these changes and acts of resistance tend to remain peripheral to the main curriculum and the messages that it imparts.

\section{Clinical legal education in a risk-filled world}

And this brings us to clinics and clinical legal education. Where are we located in this world of risk and crisis? I propose, in the footsteps of many clinical law educators, that clinical legal education is ideally situated to engaging law

Peter H. Huang and Corie Rosen Felder, “The Zombie Lawyer Apocalypse” (2015) 42 Pepperdine L Rev 727.

${ }^{37}$ Sameer M. Ashar, "Deep Critique and Democratic Lawyering in Clinical Practice" (2016) 104

California L Rev 193 at 203-204. 
Keynote Address - Clinic, the University and Society

students and law schools with the ongoing deep injustices in our world and to helping them develop the capacities to imagine and build a more just world. When we think about clinical legal education in this way, we can see that it can take its place as a crucial part of the soul of legal education - as the part of legal education where questions of injustice and justice are taken seriously and where we practice, theorize, and reflect on the role of law, legal systems, and lawyers in our world. In a time when law schools generally seem to be in search of a soul or a solid foundation, this function of clinical legal education is more important than ever. Of course, clinical legal education has in its very DNA a commitment to standing on the side of social justice and a desire to educate students for justice. One of the early American founders of clinical legal education, William Pincus, wrote that the purpose of clinical legal education is for students "to recognize what is wrong with the society around them - particularly what is wrong with the machinery of justice in which they are participating and for which they have a special responsibility." 38 Almost half a century later these words still resonate.

But there is a risk that is very present right now in clinics in Canada, and elsewhere, that clinical legal education becomes a site for skills and competencies

\footnotetext{
${ }^{38}$ William Pincus, "Educational Values in Clinical Experiences for Students", Council for Legal Education for Professional Responsibility Newsletters 1969-1972 [quoted in Stephen Wizner, "The Law School Clinic: Legal Education in the Interests of Justice" (2001-2002) 70 Fordham L Rev 1929 at 1934.
} 
training for the status quo. In Canada and elsewhere there is pressure on law schools from the legal profession and regulators to do even more to train law students to be ready to embrace practice within the context of the current order. As Sameer Ashar and others have pointed out, this current order has produced a profession that is increasingly disaggregated, outsourced, commodified, transient, and technocratic (to the point where some futurists are predicting that robots could take over many functions of lawyers). ${ }^{39}$ The danger is that by taking on a skills training mandate to prepare students to conform to the profession's desires for competency, clinics lose their ability to imagine and build new modes of practice in the face of injustice. I am reminded of a quote from the critical pedagogical writer Paulo Freire, who wrote that

"the more education becomes empty of dreams to fight for, the more the emptiness left by those dreams becomes filled with technique, until the moment comes when education becomes reduced to that. Then, education becomes pure training, it becomes pure transfer of content, it is like the training of animals, and it is a mere exercise in adapting to the world. ${ }^{40}$

\footnotetext{
${ }^{39}$ Ashar, supra note 37 at 206. See also Margaret Thornton, "Technocentrism in the Law School: Why the Gender and Colour of Law Remain the Same" (1998) 36 Osgoode Hall LJ 369 and Richard Susskind and Daniel Susskind, "Technology Will Replace Many Doctors, Lawyers, and Other Professionals" Harvard Business Review (October 11, 2016), online at https://hbr.org/2016/10/robots-will-replace-doctors-lawyers-and-other-professionals (accessed November 22, 2016).

${ }^{40}$ Paulo Freire, Pedagogy of Indignation (London: Routledge, 2004) at 84.
} 
Although I am critical of this impulse towards seeing clinical legal education as primarily skills training to adapt to the world, devoid of dreams to fight for, I also empathize with law students who are facing unprecedented pressures to become more marketable in an increasingly difficult job market, and who are graduating in many cases with overwhelming levels of tuition debt. ${ }^{41}$ They are bearing the brunt of multiple policy decisions made not by them but by many decision makers over the years, including the reduction of public investment in higher education under neoliberal regimes. ${ }^{42}$ Clinics provide valuable experiences and skills that can of course be carried forward into all sorts of legal careers, and this is fine. However, I propose that if clinics are to fulfill their potential to be the place within legal education where serious engagement with deep questions of injustice and justice occurs, then clinics need to resist pressures to become primarily sites of status quo skills and competencies training - as places where students learn techniques to merely adapt to the world.

I would like to suggest then that rather than merely training students to adapt to the world as it is, clinical legal education bears witness to a world in crisis and builds and renews the justice commitment within legal education: it can give

\footnotetext{
${ }^{41}$ See Law Students' Society of Ontario, "Just or Bust: Results of the 2014 Survey of Ontario Law Students' Tuition, Debt, \& Student Financial Aid Experiences" online at http://lsso.ca/wpcontent/uploads/2014/09/LSSO-Report-2014.pdf (accessed November 22, 2016).

42 See Margaret Thornton, "Deregulation, Debt, and the Discipline of Law" (2014) 39 Alternative L J 213 and Henry A Giroux, “Neoliberalism's War on Higher Education" (Chicago: Haymarket Books, 2014).
} 
Keynote Address - Clinic, the University and Society

legal education "dreams to fight for". I suggest that there are two essential contributions that clinical legal education makes in this regard. First, clinics are a site where we encounter, are unsettled by and learn to understand injustice. Second, clinical legal education is a site for imagining justice and new modes of legal practice that promote and even prefigure justice. In other words, clinical legal education is a place where we learn about how responding to the risks of the world is both rewarding and essential.

\section{Place to Encounter and understand injustice}

The first key contribution of clinical legal education is that it is a site where we encounter and begin to understand injustice and specifically, law's relation to injustice and harm in communities. In clinics, we are shaken awake from viewing the status quo as acceptable because we encounter the suffering and trouble that flows from our current order. We start to see more clearly how risk and violence are unevenly distributed in society so that some individuals, including most legal system insiders, are shielded from this risk while others, including most clinic clients, are immersed in it on a daily basis. ${ }^{43}$ We also begin to see how, as social

${ }^{43}$ David Abbott, Anwen Jones and Deborah Quilgars, "Social Inequality and Risk", in Peter Taylor-Gooby and Jens Zinn, eds., Risk in Social Science (Oxford: Oxford University Press, 2006) at 228. 
Keynote Address - Clinic, the University and Society

justice physician and activist Paul Farmer says "social forces ranging from poverty to racism become embodied as individual experience." ${ }^{44}$

Valerie Fournier has written that in order to seriously consider what justice requires of us, we first need to establish a "sense of estrangement" to make the "normal", the currently possible, look strange, absurd, even grotesque." ${ }^{45}$ This encounter with the absurdity and the ugliness of our "normal" world is something that happens all the time in clinical legal education. In our work at CLASSIC the situations that law students encounter are often painful and difficult. We have worked with many Indigenous men and women who have had brutal and humiliating experiences at the hands of police. We have worked with young men in prison who are held in solitary confinement, unable to contact sick family members. We have worked with people living in housing without running water or working heat in the winter, and who are evicted to become homeless. We have encountered clients who have been charged with welfare fraud when they have failed to report a small modicum of income that helps them feed their children and keep a roof over their head. Law and legal processes have sanctioned all of these situations, too often failing to curb the slow violence perpetuated by the current

\footnotetext{
${ }^{44}$ Supra note 22 at 30. Emphasis in original.

${ }^{45}$ Valerie Fournier, "Utopianism and the Cultivation of Possibilities: Grassroots Movements of Hope" in Martin Parker, ed., Utopia and Organization (Oxford: Blackwell Pub, 2002) 189 at 194.
} 
Keynote Address - Clinic, the University and Society

order and the quick and often brutal violence of the police and carceral apparatuses that protect it. ${ }^{46}$

But our ability in clinics to truly see or comprehend the injustice that we witness is incomplete if we do not work in solidarity with communities. There is a danger that we will see our clients' experiences as individual and isolated. I would suggest that this task of working with our communities to seek to understand the injustice that communities face is an area that should be central to the work of clinics, and that working with communities who are the experts in these things can be one of the hugest rewards of clinical legal education. I also think the knowledge and analysis generated through such collaborations with communities can also inspire and engage law students and legal scholars and researchers outside of the clinical context, and could be an important intellectual contribution to the mandate of law schools to engage in meaningful legal research and scholarship. ${ }^{47}$

At CLASSIC, we have embarked on a few projects that seek to work with community members to interpret and analyze injustice and to gain understanding of the impacts of the current legal regime on our community. For example, we

\footnotetext{
${ }^{46}$ See Loic Wacquant, Punishing the Poor: The Neoliberal Government of Social Insecurity (Durham: Duke University Press, 2009) for an in-depth analysis of this phenomenon. ${ }^{47}$ See Jeanne Charn and Jeffrey Selbin, "The Clinic Lab Office" (2013) 1 Wisconsin L Rev, who call for law clinics to become sites for empirical research and knowledge production.
} 
Keynote Address - Clinic, the University and Society

have engaged in community based critical education projects that bring law students and community members together - not in a relationship of lawyer and client but rather as co-learners - to delve into discussions of justice and injustice. One initiative involves bringing together law students and other university students together with former members of street gangs in a semester long class held at a local community centre. In this class, which we call "Wahkohtowin", which means "kinship" or "relationship" in Cree, we read legal texts and discuss justice issues in our city. ${ }^{48}$ For example, we read the statutory provisions that govern the use of solitary confinement in Canadian prisons - and then we discuss the legal text in light of the experiences of people in the room who have experienced directly the painful force of this text. We read Saskatoon's municipal panhandling bylaw and then discuss it in light of people's lived experiences and knowledge of how the law is mobilized against marginalized people. What has emerged from the discussions in this class is a very powerful critique of the way the legal system, despite its pretenses of objectivity or neutrality, functions too often as a club for the privileged, how law all too often fails to meaningfully check

\footnotetext{
${ }^{48}$ For more details see: Sarah Buhler, Priscilla Settee and Nancy Van Styvendale, "'We Went in as Strangers, and Left as Friends': Building Community in the Wahkohtowin Classroom" (2015) 1 Engaged Scholar Journal 96 and Sarah Buhler, Priscilla Settee and Nancy Van Styvendale, "Teaching and Learning about Justice through Wahkohtowin" (2014) 4 Annual Review of Interdisciplinary Justice Research 182.
} 
Keynote Address - Clinic, the University and Society

the exercise of power against vulnerable bodies and indeed how the words of legal texts can be transcribed violently onto the bodies of people.

We have also engaged at our clinic in community research and consultation projects, where we talk to community members and clients about their experiences in the justice system. This has helped us understand better how law and the justice system work in our community and has led to some important insights. For example, in a research project, we asked community members about their thoughts about access to justice. What we heard is requiring us to learn to reframe the problem not so much as one of access to courts and dispute resolution systems, but a problem of a justice system that is suffocating community members through welfare rules, child apprehension regimes, policing, and prisons. ${ }^{49}$

When clinics, clinical students and communities work together to name, and analyze the injustice that exists in our communities, the "normal world" becomes strange, absurd and frankly unacceptable. To quote Paulo Freire, we

\footnotetext{
${ }^{49}$ The results of this qualitative research project will be published in the future. But findings are consistent with other similar projects where members of marginalized communities have been very critical of the dominant justice system. See, for example, Amanda Dodge, "Access to Justice Metrics Informed by the Voices of Marginalized Community Members: Themes, Definitions and Recommendations Arising from Community Consultations" (paper prepared for the Canadian Bar Association Envisioning Equal Justice Initiative, 2013) online at http://www.cba.org/CBAMediaLibrary/cba na/images/Equal\%20Justice\%20\%20Microsite/PDFs/Community Voice Paper.pdf (accessed November 22, 2016). As Roderick MacDonald wrote, "[g]reater access to institutions that are the source of one's oppression is hardly a desirable outcome." Roderick A. MacDonald, "Access to Civil Justice" in Peter Cane and Herbert M. Kritzer, eds., The Oxford Handbook of Empirical Legal Research (Oxford: Oxford University Press, 2010) 492 at 518.
} 
Keynote Address - Clinic, the University and Society

begin to see that our current reality is a "perverse reality" 50 - that it is a reality that calls for change. We begin to see larger patterns that create what otherwise appear to be individual or isolated legal problems. We also confront the ways in which law and our legal system are implicated in ongoing injustice.

\section{Place to imagine \& practice justice build the world we wish to see}

And this leads me to the second major contribution of clinical legal education: and that is the creative and vital work of imagining justice and trying to understand what this demands from the legal profession. Freire wrote that it is not possible to transform the world without a dream of what justice would look like, ${ }^{51}$ and in clinics, we start to imagine and dream a more just world, and we see that the dream of justice is completely entangled up with action and work for justice. In this sense, while legal education as a whole has been described as sowing cynicism, clinical legal education is at its heart profoundly hopeful, even in the face of extraordinary risk and crisis. This is perhaps because in clinical legal education, a response to injustice is always demanded. There is no ability to sit back or retreat to a place of abstraction or pure critique. There is no ivory tower. Rather, constant action and constant reflection are required. We learn in clinics

\footnotetext{
${ }^{50}$ Supra note 40 at 72.

${ }^{51} \mathrm{Ibid}$ at 31.
} 
Keynote Address - Clinic, the University and Society

that law and the legal system are made up of humans and a relentless series of human decisions and that therefore there remain openings for change and movement within them. ${ }^{52}$ We see what Loic Wacquant means when he writes that the current injustices of the world "are not preordained necessities but the results of struggles involving myriad agents and institutions [and that] Other historical paths were open, and remain open, however narrow and improbable they may be." 53 In clinics, we learn to locate those narrow and improbable paths that may lead to a more just world.

Just as understanding injustice requires us to learn from our clients and communities who experience it directly - the work of imagining and practicing justice along those narrow and improbable paths is best done in collaboration with the marginalized yet resilient and agentic communities that are already on this journey. At CLASSIC, when we collaborate and listen to our community partners and clients, the vision of justice that arises is not an abstract one but rather is grounded in relationship and place. It has to do with healthy families, parents able to raise their children without fear of child apprehension, food security, safe

\footnotetext{
${ }^{52}$ As Valerie Fournier writes: "Nothing is the product of autonomous, inevitable, faceless forces, everything has to be decided." Supra note 45 at 200.

${ }^{53}$ Loic Wacquant, Punishing the Poor: The Neoliberal Government of Social Insecurity (Durham, NC:

Duke University Press, 2009 at xx.
} 
Keynote Address - Clinic, the University and Society

housing, and the ability to walk on the streets without fear of police, a society where youth have hope for the future.

So how do clinics respond and what does this mean for our pedagogy and practice? I think each of you and the communities with which you work will answer this differently depending on the particular way that the risk and crises of the world take form in the place where you work. At our clinic, CLASSIC, we are involved in both systemic initiatives that seek to address the underlying issues that give rise to injustice in our community, as well as a continuing commitment to individual client advocacy. Thus, CLASSIC engages in working with a renters' rights group on housing issues, working in collaboration with community partners on prison rights issues, addressing issues to do with the sentencing of Indigenous people in the criminal justice system, and many more projects.

But we also recognize that individual advocacy in courts and tribunals can be a site for practicing law in a way that tries to promote justice. At CLASSIC, we developed what we call our "philosophy of practice" in consultation with community partners, and the rich clinical literature in this area, to guide our individual advocacy with clients. This document, which acknowledges that our clients are the experts in their lives, acknowledges that legal processes are usually only one part of the solution to any problem that our clients face, and explicitly makes a social justice commitment, is a document that students grapple with and 
Keynote Address - Clinic, the University and Society

reflect on during our term. ${ }^{54}$ It helps reveal that all legal practice is rooted in (usually unstated) ideologies and philosophies, and is a good document to have on hand as students consider the roles of lawyers and law students in communities.

In our clinic, we are also seeking to try to understand whether and how legal practice can be "decolonized". This project involves lots of community engagement and work with our cultural advisor and others. It has led already to concrete changes in our practice: for example, students learn as part of their orientation to the clinic about the meaning and significance of smudging within Indigenous traditions of our territory, and learn how to smudge with clients who request this. We are incorporating education about Indigenous legal traditions in our training program. One of our Indigenous students has recently taken on a practice of acknowledging treaty territory whenever he speaks in court - a practice that calls attention to the colonial history of the institution and the larger context of land and the relationship between Indigenous and non-Indigenous people.

Sameer Ashar has argued that clinics can be vital sites for " generating new visions of practice." ${ }^{55}$ This work of imagining, theorizing, implementing and then

\footnotetext{
${ }^{54}$ See

http://www.classiclaw.ca/uploads/1/6/8/5/16850750/classic philosophy of practice approved.pd $\underline{\mathrm{f}}$

${ }^{55}$ Supra note 37 at 224 .
} 
Keynote Address - Clinic, the University and Society

critically reflecting on these new modes of practice that promote the visions of justice articulated by our communities is a crucial and deeply rewarding task of clinical legal education.

\section{Conclusion}

Paulo Freire wrote:

Nobody can be in the world, with the world, and with others in a neutral manner. ...It is impossible to study without any commitment; as if mysteriously and suddenly we had nothing to do with the world...[we must always ask] In favor of what do I study? In favor of whom? Against whom do I study?56

Now more than ever, as the injustices in our world keep mounting, as we see that law and the legal profession have helped to build and maintain this world, and as the feeling of risk and danger keeps rising around us, the fact that it is impossible to be neutral in relation to the world is more obvious than ever. In the face of this world of risk, we must continually ask, with Freire, "In favour of what do we study? Against who so we study?" I propose that clinical legal education can and should embrace its role as a central place within legal education where we study, learn and practice in favour of justice, where we study, learn and practice against injustice. This is the reward of clinical legal education in our world of risk.

\footnotetext{
56 Supra note 40 at 60.
} 